\title{
Persistence and Colonizing Ability of Rab- bitbrush Collections in a Common Garden
}

\author{
JAMES A. YOUNG, RAYMOND A. EVANS, AND B.L. KAY
}

\begin{abstract}
Collections of 4 subspecies of both green and gray rabbitbrush [Chrysothamnus viscidiflorus (Hook.) Nutt. and $C$. nauseosus (Pallas) Britton] were grown for 10 years in a common garden located in northwest Nevada. Generally, the green rabbitbrush collections did not persist as long as the gray rabbitbrush collections. C. viscidiflorus spp. pumilus (Nutt.) Hall \& Clem. had poor initial establishment and the shortest persistence of any collection tested. Only plants of $C$. viscidiflorus spp. latifolius (D.C. Eat.) Hall \& Clem. persisted for 10 years. Among the gray rabbitbrush collections, there was considerable variation in persistence within subspecies. Plants of C. nauseosus ssp. salicifolius (Rydberg) Hall \& Clem. were heavily utilized by jackrabbits (Lepus californicus). Plants of the various subspecies of green rabbitbrush were apparently never browsed by jackrabbits. Seedlings of gray rabbitbrush established naturally in the garden, especially in the plots of gray rabbitbrush.
\end{abstract}

Rabbitbrush (Chrysothamnus) constitutes a diverse and economically important group of crown-sprouting shrubs commonly occurring on sagebrush (Artemisia) rangelands and, to a lesser extent, on salt desert rangelands. The last comprehensive monograph of the genus, published by Hall and Clements in 1923, lists 4 sections, 12 species, and $\mathbf{4 0}$ subspecies. The leading contemporary taxonomist of Chrysothamnus is Loran C. Anderson, Department of Biological Sciences, Florida State University (Anderson 1970, $1978,1980,1981$ ).

Hall and Clements (1923) proposed 4 sections of the genus, 2 of which, Section 2 Typici and Section 4 Nauseosi, are of considerable interest to range managers. Section Typici includes green rabbitbrush [Chrysothamnus viscidiflorus (Hook.) Nutt.] and Section Nauseosi includes gray rabbitbrush [C. nauseosus (Pallas) Britton]. These plants are important because they are generally not preferred by browsing animals and compete with desirable browse and forage species.

Green rabbitbrush plants are often found growing in upland sagebrush communities. Green rabbitbrush is a subdominant shrub in these communities. When these communities are burned in wildfires, some rabbitbrush plants crown sprout, flower, and set seed profusely, which results in dynamic rabbitbrush seedling establishment and dominance of the site for a transitory period (Young and Evans 1974 a \& b, and 1978). Green rabbitbrush plants are difficult to control with phenoxy herbicides and improperly timed applications of phenoxy herbicides for brush control in sagebrush communities have resulted in conversion of the sites from sagebrush to green rabbitbrush dominance (Hyder et al. 1958).

Members of the gray rabbitbrush group are usually characterized by more woody plants than are found in green rabbitbrush. These plants also, instead of being distributed landscape-wide as

\footnotetext{
Authors are range scientists, USDA Agricultural Research Service, 920 Valley Road, Reno, Nev. 89512; and wildland sceding specialist, Department of Agronomy and Range Science, Univ. of California, Davis 95616.

This article is a contribution of the USDA ARS and the Nevada Agr. Exp. Sta., Univ. of Nevada, Reno. Journal Series No. 602.

Manuscript received July 22, 1983.
}

subdominants, tend to be associated with specific habitats. For example, salt rabbitbrush ( $C$. nauseosus ssp. consimilis Greene) is often found growing in areas with a shallow water table in salt desert communities (Roundy et al. 1981). This species is plastic enough to be adapted to other environments, including upland sites without salt-affected soils. Hall and Clements (1923) reported that 47 subspecies of $C$. nauseosus had been proposed, all but 8 of which having been proposed at the species level at one time or another. Anderson $(1978,1980,1981)$ recognizes 21 subspecies for C. nauseosus. The species is so variable that virtually any collection represents a morphologically distinct genotype.

The subspecies of $C$. nauseosus have preferred habitats (Plummer 1977), but occasionally 2 or more subspecies may be found together in the same habitat. Some hybridization and introgression may occur at these sites (Hanks et al. 1975), but because of flower structure the rabbitbrush species are largely self pollinated, and only minimally outcrossed (Anderson 1966, McArthur et al. 1979).

Our purpose was to evaluate the persistence and natural regeneration of collections of green and gray rabbitbrush grown in a common garden for 10 years.

\section{Methods and Materials}

A common garden was established in 1972 at Granite Peak 35 $\mathrm{km}$ north of Reno, Nev. The site is situated at 1,800 -m elevation on a north, north-easterly facing slope. The soils are Typic Haplargids. The surface soil has a sandy-loam texture and is derived from decomposed granite. Average annual precipitation for the past 14 years was $32.5 \mathrm{~cm}$. Precipitation largely occurs during winter and spring. The site supported a mid-seral community of mountain big sagebrush [Artemisia tridentata ssp. vaseyana (Rydb.) Beetle]/green rabbitbrush [C. viscidiflorus ssp. viscidiflorus (Hook.) Nutt.] with a few scattered plants of Thurber's needlegrass (Stipa thurberiana Piper) in an understory generally dominated by Sandberg bluegrass (Poa secunda Presl.). The site was prepared for transplanting by plowing and disk-harrowing. Seedlings of the rabbitbrush plants that had been grown in $15-\mathrm{cm}$ pots for 1 year were transplanted into the garden site during April. No supplemental water or weed control was provided after transplanting.

The transplants were established on $1-\mathrm{m}$ centers with 5 plants per replication and 4 replications in a randomized block design.

We compared 2 collections of each of 4 widely distributed subspecies of gray and green rabbitbrush (Table 1).

Annually, in October, the persistence of the individual shrubs was recorded along with notes on flower production and utilization by jackrabbits (Lepus californicus). Flower production was recorded on a scale of 1 to 10 with 1 indicating no flowers and 10 including the complete crown of the shrubs covered with flowers. Jackrabbit utilization was rated on a scale from 1 to 10 with 1 indicating no detectable use and 10 indicating the entire plant hedged to coarse stems.

In September 1982, the garden was sampled for the last time; 2-meter-square plots were located in each of the replications and the density of rabbitbrush seedlings was recorded. The sampled 
Table 1. Collections of green and gray rabbitbrush grown in a common garden 1972-1982.

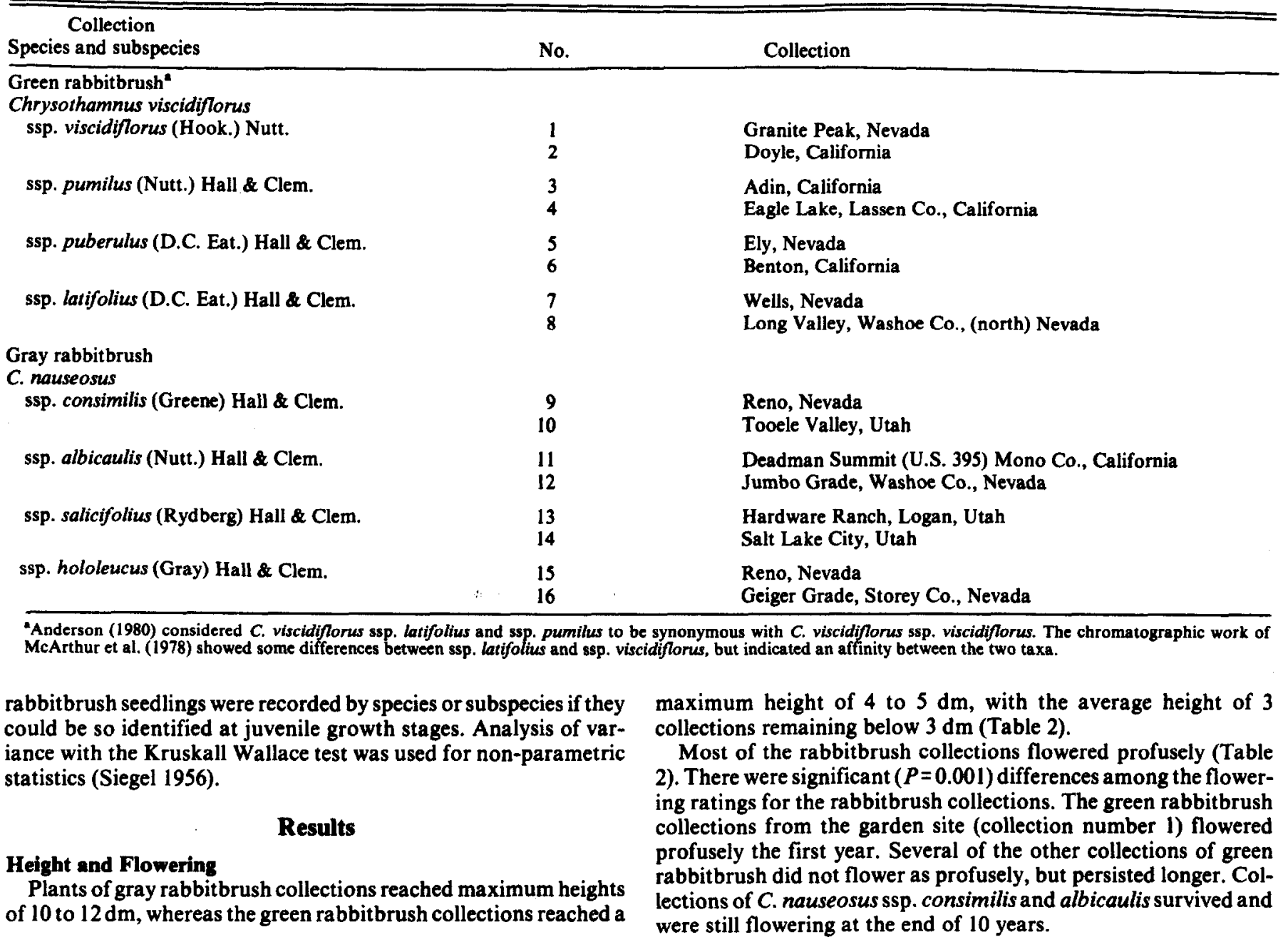

Table 2. Maximum height, flower production at 2, 5, and 10 years, and jackrabbit utilization of green and gray rabbltbrush plants."

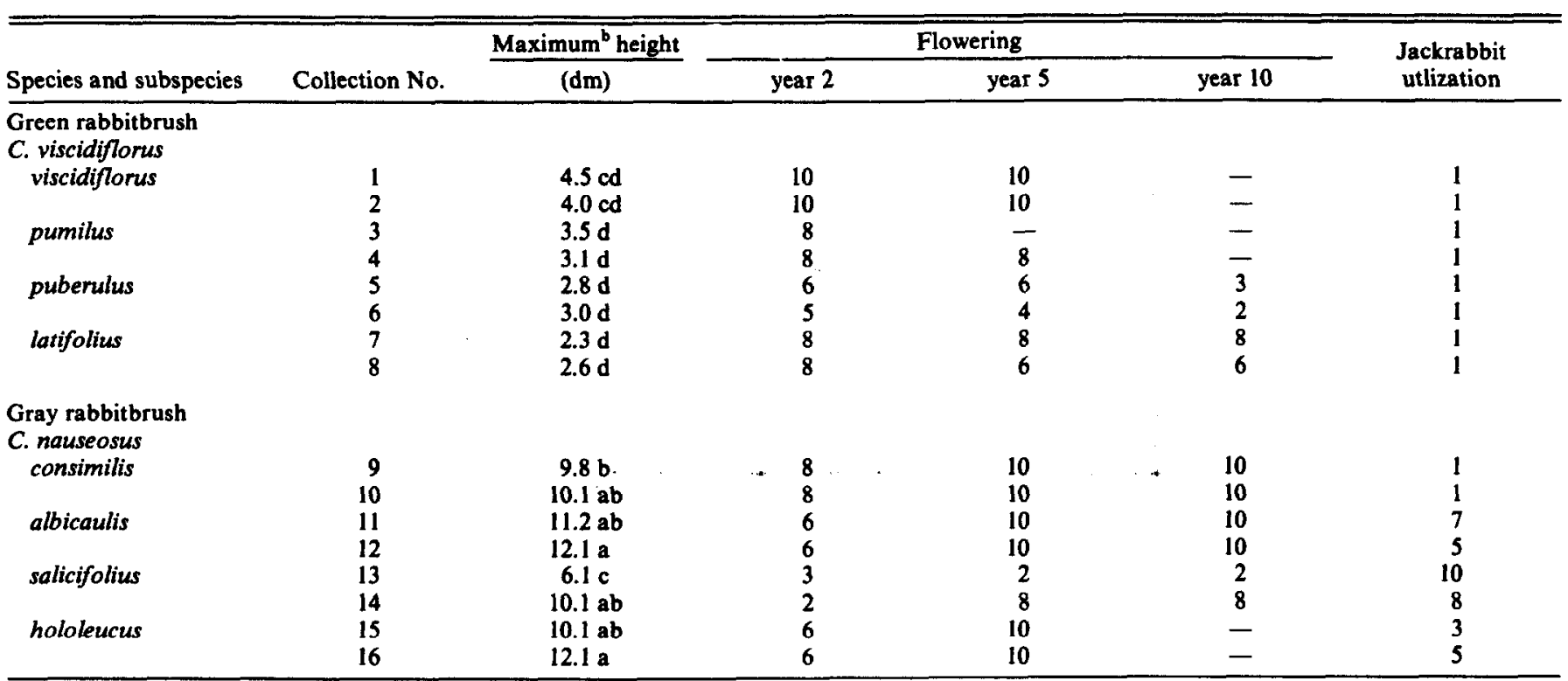

Flowering scale 1 to 10 with 1 indicating no flowers and 10 indicating entire crown covered with flowers.

-Indicates plants were dead by loth year.

Jackrabbit utilization on scale of 1 to 10 with indicating no utilization and 10 indicating entire shrub browsed to coarse twigs $0.75 \mathrm{~cm}$ in diameter.

beans followed by the same letter are not significantly different at 0.01 level of probability as determined by Duncan's multiple range test. 


\section{Jackrabbit Utilization}

The green rabbitbrush collections were apparently never browsed by jackrabbits (Table 2 ). The gray rabbitbrush collections differed significantly $(P=0.001)$ in their browsing indices according to the Kruskall-Wallace test (Siegel 1956). Collection number 13 of $C$. nauseosus ssp. salicifolius was severely hedged by jackrabbits. The average height of collection 13 was significantly $(P=0.01)$ reduced compared to collection 14, the other representative of the $C$. nauseosus ssp. salicifolius.

The shoots of collections 11 and 12 of $C$. nauseosus ssp. albicaulis were utilized by jackrabbits, but not to the extent that the plants were severely hedged or that flowering was reduced. We did not detect jackrabbit utilization of the stems of $C$. nauseosus spp. consimilis. Studies in Utah have shown that $C$. nauseosus ssp. salicifolius and albicaulis are more highly preferred by browsing animals than the shoots of $C$. nauseosus ssp. consimilis (Hanks et al. 1975).

\section{Establishment and Persistence}

The transplants of all collections of rabbitbrush had excellent first year establishment except collection number $4, C$. viscidiflorus spp. pumilus, although $80 \%$ of the plants of this source became established (Table 3). The other collection of this subspecies had excellent establishment, but only persisted for 2 years.

Collection number 1 of green rabbitbrush, $C$. viscidiflorus ssp. viscidiflorus, was collected at the site of the common garden. When these plants were transplanted back on the site on 1 -m centers, they initially established very well ( $95 \%$ survival), but were all dead by 8 years (Table 3). Studies of native stands in the general area have shown that when green rabbitbrush plants invade burned areas, they generally dominate the site for about 10 to 15 years (Young and Evans 1974b).

The subspecies of green rabbitbrush with the greatest persistence was $C$. viscidiflorus ssp. latifolius, but by 10 years only 5 and $15 \%$ of the plants of the 2 collections tested had survived.

All of the gray rabbitbrush plants of collection $10, C$. nauseosus ssp. consimilis, and collection $12, C$. nauseosus ssp. albicaulis, survived for the 10-year duration of the common garden (Table 3). The other collection of $C$. nauseosus ssp. consimilis (number 9 ) had only $10 \%$ survival at 10 years, and the other collection of $C$. nauseosus ssp. albicaulis (number 11) had only 5\% survival at 10 years. The subspecies of gray rabbitbrush with the poorest overall survival was $C$. nauseosus ssp. hololeucus. The survival and persistence of plants of $C$. nauseosus ssp. salicifolius was probably limited by rather severe utilization by jackrabbits.

We developed regression equations for the relationship between survival and time in the common garden for each rabbitbrush collection. Some of these are meaningless, because all plants of a collection were still alive after 10 years when the last data collection was made (collections 10 and 12, Table 3 ). For collection number 1

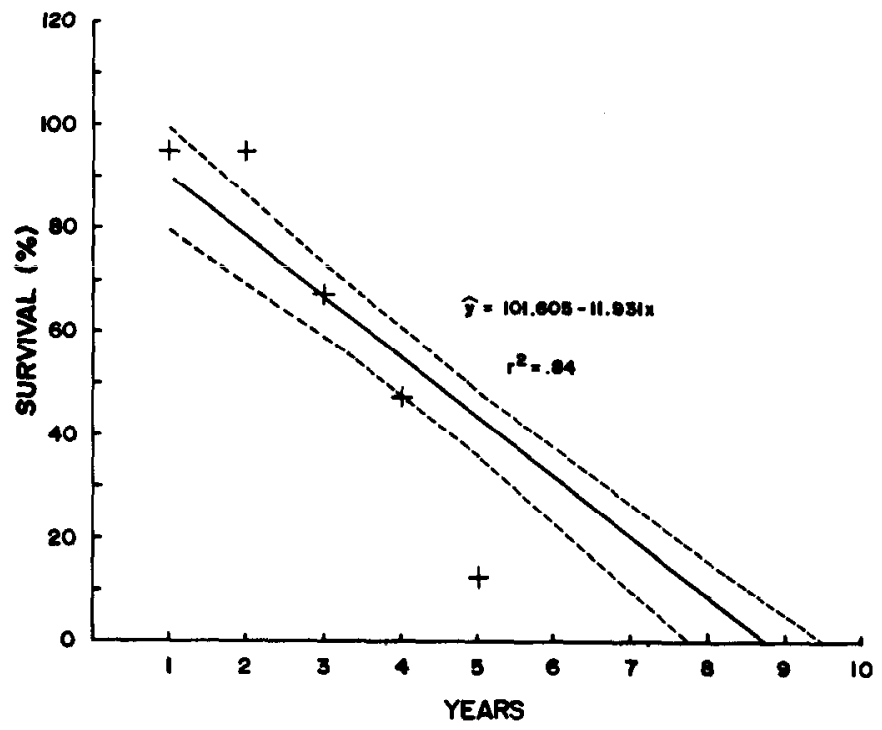

Fig. 1. Multiple regression equation with confidence interval $(\mathrm{P}=0.01)$ and coefficient of determination for relationship between survival of Chrysothamnus viscidiflorus ssp viscidiflorus plants and time in a common garden located at Granite Peak, Nev.

Table 3. Survival of green and gray rabbitbrush plants grown in a common garden for 10 years."

\begin{tabular}{|c|c|c|c|c|c|c|c|c|}
\hline \multirow[b]{2}{*}{ Species \& Subspecies } & \multirow[b]{2}{*}{ Collection No. } & \multicolumn{7}{|c|}{ Survival in Years } \\
\hline & & 1 & 2 & 3 & 4 & 5 & 8 & 10 \\
\hline $\begin{array}{l}\text { Greeen râtbittorushì } \\
\text { C. viscidiflorus } \\
\text { viscidiflorus }\end{array}$ & $\begin{array}{l}1 \\
2\end{array}$ & $\begin{array}{r}95 \mathrm{a} \\
100 \mathrm{a}\end{array}$ & $\begin{array}{r}95 a \\
100 a\end{array}$ & $\begin{array}{l}68 \mathrm{~cd} \\
33 \mathrm{c}\end{array}$ & $\begin{array}{l}48 \mathrm{f} \\
20 \mathrm{~g}\end{array}$ & $\begin{array}{l}15 \mathrm{de} \\
10 \mathrm{df}\end{array}$ & $\begin{array}{l}0 \mathrm{~g} \\
0 \mathrm{~g}\end{array}$ & $\begin{array}{l}\text { De } \\
0 \mathbf{e}\end{array}$ \\
\hline pumilus & $\begin{array}{l}3 \\
4\end{array}$ & $\begin{array}{l}95 a \\
80 b\end{array}$ & $\begin{array}{l}63 \mathrm{e} \\
78 \mathrm{bc}\end{array}$ & $\begin{array}{l}74 \mathrm{~cd} \\
36 \mathrm{e}\end{array}$ & $\begin{array}{l}10 \mathrm{~h} \\
36 \mathrm{f}\end{array}$ & $\begin{array}{c}0 \mathrm{~g} \\
10 \mathrm{df}\end{array}$ & $\begin{array}{l}\mathbf{0 g} \\
\mathbf{0 g}\end{array}$ & $\begin{array}{l}0 c \\
0 e\end{array}$ \\
\hline puberulus & $\begin{array}{l}5 \\
6\end{array}$ & $\begin{array}{l}100 \mathrm{a} \\
100 \mathrm{a}\end{array}$ & $\begin{array}{l}78 \mathrm{bc} \\
69 \mathrm{ce}\end{array}$ & $\begin{array}{l}66 \mathrm{~cd} \\
41 \mathrm{e}\end{array}$ & $\begin{array}{l}36 f \\
41 \bar{f}\end{array}$ & $\begin{array}{l}\text { 10df } \\
15 d e\end{array}$ & $\begin{array}{r}10 \mathrm{df} \\
5 \mathrm{eg}\end{array}$ & $\begin{array}{l}\text { De } \\
\text { De }\end{array}$ \\
\hline latifolius & $\begin{array}{l}7 \\
8\end{array}$ & $\begin{array}{r}95 a \\
100 a\end{array}$ & $\begin{array}{r}81 b \\
100 a\end{array}$ & $\begin{array}{l}81 b c \\
100 a\end{array}$ & $\begin{array}{l}43 \mathrm{f} \\
93 \mathrm{ab}\end{array}$ & $\begin{array}{l}60 \mathrm{~b} \\
80 \mathrm{~b}\end{array}$ & $\begin{array}{l}25 \mathrm{c} \\
60 \mathrm{~b}\end{array}$ & $\begin{array}{l}\text { Sde } \\
15 c\end{array}$ \\
\hline $\begin{array}{l}\text { Gray rabbitbrush } \\
\text { C. nauseosus } \\
\text { consimilis }\end{array}$ & $\begin{array}{r}9 \\
10\end{array}$ & $\begin{array}{l}100 \mathrm{a} \\
100 \mathrm{a}\end{array}$ & $\begin{array}{l}100 \mathrm{a} \\
100 \mathrm{a}\end{array}$ & $\begin{array}{c}83 \mathrm{bc} \\
100 \mathrm{a}\end{array}$ & $\begin{array}{l}71 \mathrm{~cd} \\
100 \mathrm{a}\end{array}$ & $\begin{array}{r}50 \mathrm{~b} \\
100 \mathrm{a}\end{array}$ & $\begin{array}{r}35 \\
100\end{array}$ & $\begin{array}{c}\text { 10de } \\
100 \mathrm{a}\end{array}$ \\
\hline albicaulis & $\begin{array}{l}11 \\
12\end{array}$ & $\begin{array}{r}95 a \\
100 a\end{array}$ & $\begin{array}{r}95 a \\
100 a\end{array}$ & $\begin{array}{l}95 \mathrm{ab} \\
100 \mathrm{a}\end{array}$ & $\begin{array}{l}\text { 66de } \\
100 \mathrm{a}\end{array}$ & $\begin{array}{r}40 \mathrm{~b} \\
100 \mathrm{a}\end{array}$ & $\begin{array}{r}20 \\
100\end{array}$ & $\begin{array}{c}5 \\
100 \mathrm{a}\end{array}$ \\
\hline salicifolius & $\begin{array}{l}13 \\
14\end{array}$ & $\begin{array}{r}100 \mathrm{a} \\
95 \mathrm{a}\end{array}$ & $\begin{array}{l}71 \mathrm{bec} \\
\text { 66de }\end{array}$ & $\begin{array}{l}\text { 6ld } \\
\text { 66cd }\end{array}$ & $\begin{array}{l}48 f \\
53 \mathrm{ef}\end{array}$ & $\begin{array}{l}40 b \\
55 b\end{array}$ & $\begin{array}{l}40 \\
55\end{array}$ & $\begin{array}{l}40 \mathrm{~b} \\
35 \mathrm{~b}\end{array}$ \\
\hline hololeucus & $\begin{array}{l}15 \\
16\end{array}$ & $\begin{array}{l}100 a \\
100 a\end{array}$ & $\begin{array}{l}100 \mathrm{a} \\
100 \mathrm{a}\end{array}$ & $\begin{array}{l}100 \mathrm{a} \\
78 \mathrm{~cd}\end{array}$ & $\begin{array}{l}83 b c \\
65 d d e\end{array}$ & $\begin{array}{l}45 \mathrm{~b} \\
35 \mathrm{c}\end{array}$ & $\begin{array}{r}15 \\
0\end{array}$ & $\begin{array}{l}\text { De } \\
\text { oe }\end{array}$ \\
\hline
\end{tabular}

"Means within columns followed by the same letter are not significantly different at the 0.01 level of probability as determined by Duncan's multiple range test. 
of $C$. viscidiflorus spp. viscidiflorus the coefficient of determination $\left(r^{2}\right)$ for the relationship between time and survival was $\mathbf{0 . 8 4}$ (Fig. 1). This was fairly typical for the green rabbitbrush collections.

The gray rabbitbrush collections were longer lived as typified by collection number 9 of the C. nauseosus ssp. consimilis (Fig. 2).

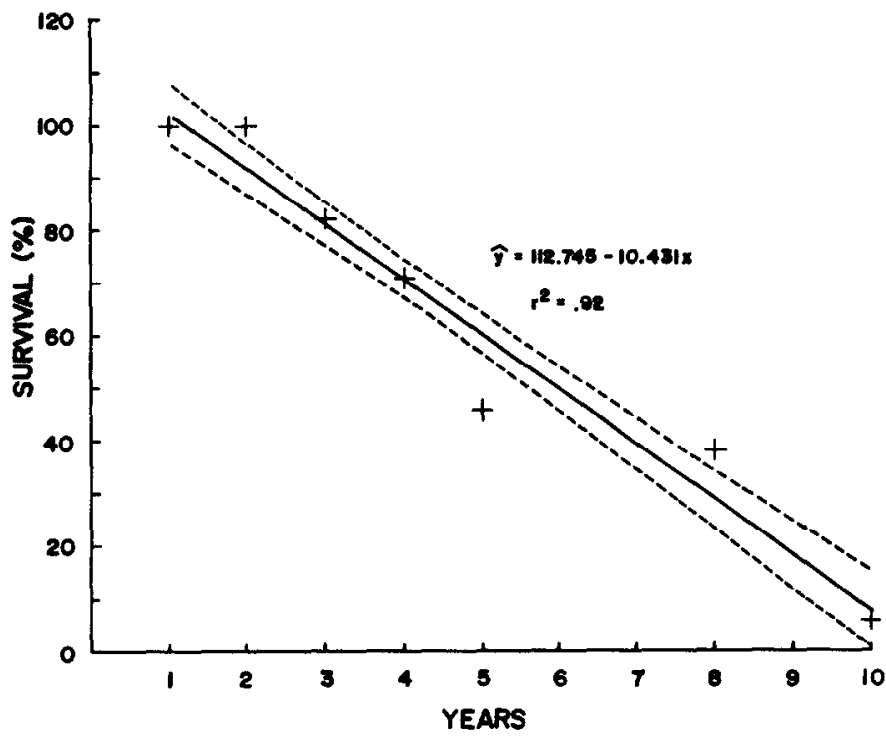

Fit. 2. Multiple regression equation with confidence interval $(\mathbf{P}=0.01)$ and coefficient of determination for relationship between survival of Chrysothamnus nausosus ssp. consimilis and time in a common garden located at Granite Peak, Nev.

Correlation between persistence and time was low for collections 13 and 14 of $C$. nauseosus ssp. salicifolius because plant survival was influenced by rabbitbrush predation.

If the garden had been developed with greater spacing among plants, survival of all collections probably would have been extended. However, the same relative persistence probably would have been apparent. If one assumes equal chance of seed distribution from the randomized block arrangement of the common garden, it would appear that collection number 10 of $C$. nauseosus ssp. consimilis was the most successful colonizing plant material in the garden. This rating is based on the total density of seedlings in all plots and the exclusion of seedlings of other subspecies of gray rabbitbrush from plots of $C$. nauseosus ssp. consimilis.

The remarkable part of the persistence and colonizing ability of the collection of $C$. nauseosus ssp. consimilis is that the plant material is almost never found growing naturally on the soils or in the natural vegetation of the site of the common garden. The subspecies is adapted to saline/alkaline environments.

\section{Rabbitbrush Seedling Establishment}

Many rabbitbrush seedlings established naturally in the common garden, and most were seedlings of gray rabbitbrush (Table 4). Seedlings of $C$. nauseosus spp. consimilis were quite distinguishable from seedlings of other gray rabbitbrush subspecies and there were about 1.5 times as many of them as all other gray rabbitbrush seedlings. In many of the plots, the density of seedlings far exceeded what is ordinarily found in plant communities, and probably seedling numbers exceeded the site potential, although some of the seedlings were flowering in 1982.

The greatest density of rabbitbrush seedlings was found in plots of $C$. nauseosus ssp. hololeucus (Table 4). Seedlings in these plots were comprised of $46 \% C$. nauseosus ssp. consimilis and the remainder of other gray rabbitbrush subspecies. Plots of $C$. nauseosus ssp. consimilis did not contain any seedlings of other subspecies of gray rabbitbrush. Plots of collection 12 of $C$. nauseosus ssp. albicaulis did not contain any seedlings of $C$. nauseosus ssp.
Table 4. Density (per $\mathrm{m}^{2}$ ) of green and gray rabbitbrush seedlings growing between mature rabbitbrush plants in a 10-year-old common zarden. Gray rabbitbrush seedlinga are classified as belong to the $C$. nauseosus consimilis or other subspecies."

\begin{tabular}{|c|c|c|c|c|c|}
\hline \multirow[b]{2}{*}{$\begin{array}{l}\text { Species \& } \\
\text { Subspecies }\end{array}$} & \multirow[b]{2}{*}{$\begin{array}{c}\text { Collection } \\
\text { No. }\end{array}$} & \multicolumn{4}{|c|}{ Rabbitbrush Seedling Density } \\
\hline & & Green & $\begin{array}{l}\text { Consi- } \\
\text { milis }\end{array}$ & $\begin{array}{l}\text { Gray } \\
\text { Other }\end{array}$ & Total \\
\hline \multicolumn{6}{|l|}{$\begin{array}{l}\text { Green rabbitbrush } \\
\text { C. viscidiflorus }\end{array}$} \\
\hline viscidiflorus & $\begin{array}{l}1 \\
2\end{array}$ & $\begin{array}{l}2 \\
0\end{array}$ & $\begin{array}{l}18 b-d \\
22 a b\end{array}$ & $\begin{array}{l}\text { Od } \\
\text { Od }\end{array}$ & $\begin{array}{l}20 \mathrm{bc} \\
22 \mathrm{bc}\end{array}$ \\
\hline pumilus & $\begin{array}{l}3 \\
4\end{array}$ & $\begin{array}{l}0 \\
0\end{array}$ & $\begin{array}{l}5 \mathrm{gh} \\
12 \mathrm{fg}\end{array}$ & $\begin{array}{l}5 \mathrm{~cd} \\
4 \mathrm{~d}\end{array}$ & $\begin{array}{l}10 \text { ef } \\
16 \text { de }\end{array}$ \\
\hline puberulus & $\begin{array}{l}5 \\
6\end{array}$ & $\begin{array}{l}0 \\
0\end{array}$ & $\begin{array}{l}4 \mathrm{gh} \\
4 \mathrm{gh}\end{array}$ & $\begin{array}{r}11 \mathbf{b} \\
3 \mathbf{d}\end{array}$ & $\begin{array}{r}15 \mathrm{de} \\
7 \mathrm{fg}\end{array}$ \\
\hline latifolius & $\begin{array}{l}7 \\
8\end{array}$ & $\begin{array}{l}0 \\
0\end{array}$ & $\begin{array}{l}\text { Oh } \\
\text { Ohnf }\end{array}$ & 1d & $\begin{array}{l}1 \mathrm{~g} \\
3 \mathrm{~g}\end{array}$ \\
\hline \multicolumn{6}{|l|}{$\begin{array}{l}\text { Gray rabbitbrush } \\
\text { C. nauseosus }\end{array}$} \\
\hline consimilis & $\begin{array}{r}9 \\
10\end{array}$ & $\begin{array}{l}0 \\
0\end{array}$ & $\begin{array}{l}21 a-c \\
26 a\end{array}$ & $\begin{array}{l}\text { Od } \\
\text { Od }\end{array}$ & $\begin{array}{l}21 b c \\
26 a b\end{array}$ \\
\hline albicaulis & $\begin{array}{l}11 \\
12\end{array}$ & $\begin{array}{l}0 \\
0\end{array}$ & $\begin{array}{l}5 \mathrm{gh} \\
0 \mathrm{~h}\end{array}$ & $\begin{array}{l}18 a \\
18 a\end{array}$ & $\begin{array}{l}23 \mathrm{bc} \\
18 \mathrm{~cd}\end{array}$ \\
\hline salicifolius & $\begin{array}{l}13 \\
14\end{array}$ & $\begin{array}{l}0 \\
0\end{array}$ & $\begin{array}{r}7 f-h \\
13 d-f\end{array}$ & $\begin{array}{l}8 b c \\
4\end{array}$ & $\begin{array}{l}15 \mathrm{de} \\
17 \mathrm{~cd}\end{array}$ \\
\hline hololeucus & $\begin{array}{l}15 \\
16\end{array}$ & $\begin{array}{l}0 \\
0\end{array}$ & $\begin{array}{l}15 c-e \\
10 e-g\end{array}$ & $\begin{array}{l}18 a \\
11 b\end{array}$ & $\begin{array}{l}33 a \\
21 b c\end{array}$ \\
\hline
\end{tabular}

Means followed by the same letter within columns are not significantly different at the 0.01 level of probability as determined by Duncan's multiple range test.

consimilis. In plots of the other collection of $C$. nauseosus ssp. albicaulis $22 \%$ of the seedlings belonged to $C$. nauseosus ssp. consimilis.

In contrast to the very high rabbitbrush seedling density in most plots of gray rabbitbrush, the plots of $C$. viscidiflorus ssp. latifolius had very few seedlings (Table 4). All plots of green rabbitbrush averaged only 12 seedlings per $\mathrm{m}^{2}$, whereas the plots of gray rabbitbrush averaged 22 rabbitbrush seedlings per $\mathrm{m}^{2}$. Remember all of the green rabbitbrush plants, except a low percentage of the plants of $C$. viscidiflorus ssp. latifolius were dead by the 10 th year of the garden.

A complicating factor in rabbitbrush seedling establishment was the presence of cheatgrass (Bromus tectorum L.). This highly competitive annual infested the green rabbitbrush plots and utilized the environmental potential, especially after most of the shrubs died. The meter-tall and vigorous gray rabbitbrush plants growing on only $1-\mathrm{m}$ centers largely suppressed the understory of cheatgrass. Cheatgrass can out compete seedlings of perennial grasses for moisture in this environment (Evans et al. 1970) and competition for moisture may play a role in rabbitbrush seedling establishment with high water tables (Roundy et al. 1981). Adaptation of subspecies of rabbitbrush to specific environments may be predicated on factors other than moisture availability, mineral nutrition, and light. Biotic factors such as insect predators (Young and Evans 1974b), susceptibility to grazing, or the nature and amount of sprouting after being burned in wildfires may be at least partly responsible for distribution patterns. Robertson and Cords (1957) suggest that some forms of gray rabbitbrush were relatively susceptible to fire because they sprouted from stem buds rather than crown buds. Hanks et al. (1975) indicated much variability in utilization by sheep among subspecies of gray rabbitbrush. Results of this study establish patterns of jackrabbit utilization similar to those found in sheep. Severe defoliation of rabbitbrush by rabbits, especially in dry zones, might be very detrimental.

Results of the study hint at the remarkable diversity among 
subspecies of rabbitbrush in important characteristics that affect survivability in relation to many factors on rangelands. Knowledge of this diversity can also be utilized in decisions of range managers' control and revegetation projects.

\section{Literature Cited}

Anderson, L.C. 1966. Cytotaxonomic studies in Chrysothamnus (Asteraceae, Compositae). Amer. J. Bot. 53:204-212.

Anderson, L.C. 1970. Flora anatomy of Chrysothamnus (Asteraceae, Compositae). Sida 3:466-503.

Anderson, L.C. 1978. New taxa in Chrysothamnus, Section nauseosi (Asteraceae). Phytologia 38:309-320.

Anderson, L.C. 1980. Identity of narrow-leafed Chrysothamnus viscidiflorus (Asteraceae). Great Basin Nat. 40:117-120.

Anderson, L.C. 1981. Chrysothamnus nauseosus ssp. iridis (Asteraceae): A new endemic from Utah. Great Basin Nat. 41:311-313.

Evans, R.A., H.R. Holbo, R.E. Eckert, Jr., and J.A. Young 1970. Functional environment of downy brome communities in relation to weed control and revegetation. Weed Sci. 18:154-162.

Hall, H.M. and F.E. Clements. 1923. Genus Chrysothamnus. p 157-234. In: The Phylogenetic Method in Taxonomy. Carnegie Institution of Washington, Washington, D.C.

Hanks, D.L., E.D. McArthur, A.D. Plummer, B.C. Giunta, and A.C. Blauer. 1975. Chromatographic recognition of some palatable and unpalatable subspecies of rubber rabbitbrush in and around Utah. $J$. Range Manage. 28:144-148.
Hyder, D.N., F.A. Sneva, D.0. Chilcote, and W.R. Furtick. 1958. Chemical control of rabbitbrush with emphasis upon simultaneous control of big sagebrush. Weeds 6:289-297.

McArthur, E.D., D.L. Hanks, A.P. Plummer, and H.C. Blauer. 1978. Contributions to the taxonomy of Chrysothamnus visicidiflorus (Asteraceae, Compositae) and other Chrysothamnus species using paper chromatography.

MCArthur, E.D., C.F. Tiernan, and B.L. Welch. 1979. Subspecies specificity of all forms of Chrysothamnus nauseosus. Great Basin Nat. 39:81-87.

Plummer, A.P. 1977. Revegetation of disturbed Intermountain area sites. p. 302-339. In: J.L. Thames (ed.), Reclamation and use of disturbed land in the Southwest. Univ. Arizona Press, Tucson.

Robertson, J.H., and H.P. Cords. 1957. Survival of rabbitbrush Chrysothamnus ssp., following chemical, burning, and mechanical treatments. J. Range Manage. 10:83-89.

Roundy, B.A., J.A. Young, and R.A. Evans, 1981. Phenology of salt rabbitbrush (Chrysothamnus nauseosus ssp. consimilis) and greasewood (Sarcobatus vermiculatus). Weed Sci. 29:445-454.

Siegel, S. 1956. New parametric statistics for the behavioral sciences. McGraw-Hill. p. 184-194.

Young, J.A., and R.A. Evans. 1974a. Phenology of Chrysothamnus viscidiflorus subspecies viscidiflorus (Hook.) Nutt. Weed Sci. 22:469-475.

Young, J.A., and R.A. Evans. 1974b. Population dynamics of green rabbitbrush in disturbed big sagebrush communities. J. Range Manage. 27:127-132.

Young, J.A., and R.A. Evans. 1978. Population dynamics after wildfire in sagebrush grasslands. J. Range Manage. 31:283-289. 